\title{
OPTIMIZATION OF THE ANNEALING OF PLASTER MOULDS FOR THE MANUFACTURE OF METALLIC FOAMS WITH AN IRREGULAR CELL STRUCTURE
}

\author{
OPTIMIRANJE POSTOPKA ŽARJENJA MAVČNIH FORM ZA \\ IZDELAVO KOVINSKIH PEN Z NEPRAVILNO STRUKTURO CELIC
}

\author{
Ivana Kroupová1, Petr Lichý1 ${ }^{1}$, Filip Radkovský1 ${ }^{1}$, Jaroslav Beňo, \\ Vlasta Bednářová ${ }^{1}$, Ivo Lána ${ }^{2}$ \\ ${ }^{1}$ VŠB-Technical University of Ostrava, Faculty of Metallurgy and Materials Engineering, Department of Metallurgy and Foundry Engineering, \\ 17. listopadu 15/2172, 70833 Ostrava, Czech Republic \\ 2Slévárna a modelárna Nové Ransko, s.r.o., Nové Ransko 234, 58263 Ždírec nad Doubravou, Czech Republic \\ ivana.kroupova@vsb.cz \\ Prejem rokopisa - received: 2014-07-30; sprejem za objavo - accepted for publication: 2014-10-02
}

doi: $10.17222 /$ mit.2014.132

\begin{abstract}
Metallic foams are the materials, the research of which is still ongoing, with a broad applicability in many different areas (e.g. automotive industry, building industry, medicine, etc.). These materials have interesting potentials due to a combination of properties, which are, on the one hand, related to their metallic character and, on the other hand, to the porous structure. Since the discovery of porous metallic materials numerous methods of production have been developed. This work deals with the optimization of the foundry method for the manufacture of metallic foams using the evaporable polymeric pattern. This technology was used for the manufacture of metallic foams with an irregular cell structure and with fully open pores. Attention, in the experimental part, is devoted particularly to the chosen moulding material - plaster. We checked the suitably of the proposed procedure of manufacturing a plaster mould, the drying process and the subsequent annealing that significantly influence the final properties of the mould and, therefore, the quality of the resulting casting of the metallic foam.

Keywords: metallic foams, casting, irregular cell structure, plaster, annealing
\end{abstract}

Kovinske pene so materiali, ki se še preiskujejo in imajo široko področje uporabnosti na različnih področjih (npr. avtomobilska industrija, gradbena industrija, medicina in podobno). Ti materiali so perspektivni zaradi kombinacije lastnosti, ki imajo po eni strani kovinske lastnosti, po drugi pa porozno strukturo. Od odkritja poroznih kovinskih materialov so se razvile številne metode njihove izdelave. Delo obravnava optimizacijo livarske metode izdelave kovinske pene z uporabo izparljivega polimernega modela. Ta tehnologija je bila uporabljena za izdelavo kovinske pene z nepravilno celično strukturo in popolnoma odprtimi porami. V eksperimentalnem delu je pozornost usmerjena v izbiro mavca kot materiala za model. Preverjen je bil predlagani postopek izdelave mavčnega modela, postopka sušenja in žarjenja, ki imajo največji vpliv na končne lastnosti modela in na kvaliteto ulivanja kovinske pene.

Ključne besede: kovinske pene, ulitek, nepravilna struktura celic, mavec, žarjenje

\section{INTRODUCTION}

Metallic foams and porous metals are the materials that contain artificially created pores. These pores give them specific properties such as a large rigidity maintaining a low density, high temperature conductivity, the capability to absorb energy, etc.

The first mention of metal foams was recorded already at the beginning of the $20^{\text {th }}$ century when these porous metal materials started to be used for engineering purposes. In the 1920 s they began to be commercially produced by sintering metal powders and used for filters, batteries and self-lubricating bearings. A French patent from 1925 mentions metal foams made by foaming and thirty years later their commercial use was started in the United States. But extensive research-and-development activities started in the 1990s and they have been in progress up to now.

At the VSB - Technical University of Ostrava, the research dealing with the optimization of the production of this unique material in a foundry is currently underway.

\subsection{Present trends for metallic-foam manufactures}

Since the discovery of the porous metallic materials numerous methods of production have been developed. Some technologies are similar to those for polymer foaming, others are developed with regard to the characteristic properties of metallic materials, such as their ability to be sintered or the fact that they can be deposited electrolytically. ${ }^{1}$

According to the state, in which a metal is processed, the manufacturing processes can be divided into four groups. Porous metallic materials can be made from:2,3

- a liquid metal (e.g., direct foaming with gas, blowing agents, powder-compact melting, casting, spray forming)

- a powdered metal (e.g., sintering of powders, fibres or hollow spheres, extrusion of polymer/metal mixtures, reaction sintering) 


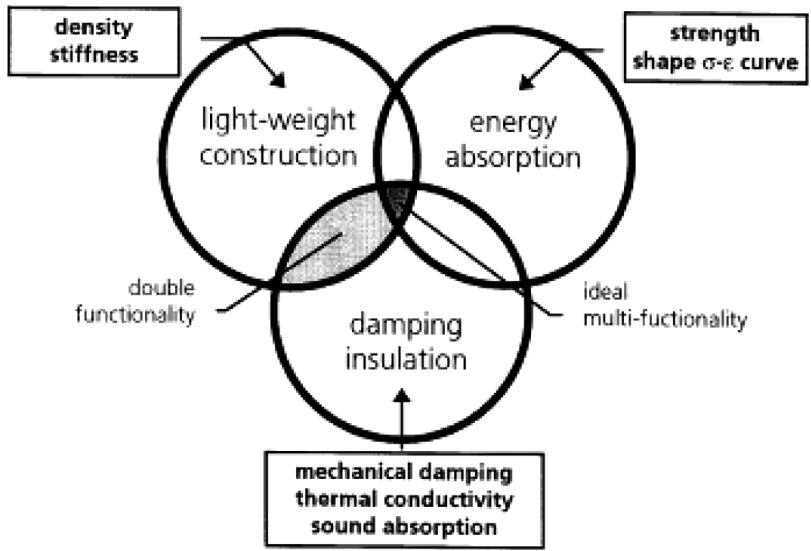

Figure 1: Application fields of structural metal foams ${ }^{4}$ Slika 1: Področja uporabnosti kovinskih pen ${ }^{4}$

- metal vapours (vapour deposition)

- metal ions (electrochemical deposition).

\subsection{Properties and utilization of metallic foams}

Foams and other highly porous materials with a cell structure are known for a combination of many interesting physical and mechanical properties, such as high stiffness at a low density, high thermal conductivity, the ability of energy absorption, etc. (Figure 1). ${ }^{4}$ The use of a foam material is optimal in the cases when at least two or more its merits are used at the same time.

The most important parameters for these porous materials are the porosity, the pore diameter, the pore size, distribution, shape, orientation, the degree of the interconnection of the pores. Further, the characteristics of the base material - the alloy - or the density of the created material are also important.

The size, shape, distribution and degree of the interconnection of the pores influence the resulting properties of metal foams. These parameters affect, in particular,
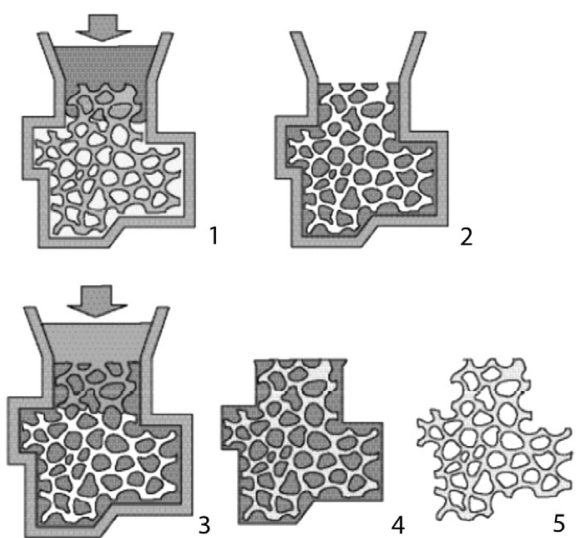

Figure 2: 1 - polymer foam infiltrated with plaster, 2 - removed polymer, 3 - infiltration with metal, 4 - metal foam in the mould, 5 removed mould, final metal foam

Slika 2: 1 - polimerna pena, prepojena $\mathrm{z}$ mavcem, 2 - odstranjeni polimer, 3 - prepojitev s kovino, 4 - kovinska pena in forma, 5 odstranjena forma; končna kovinska pena ${ }^{5}$

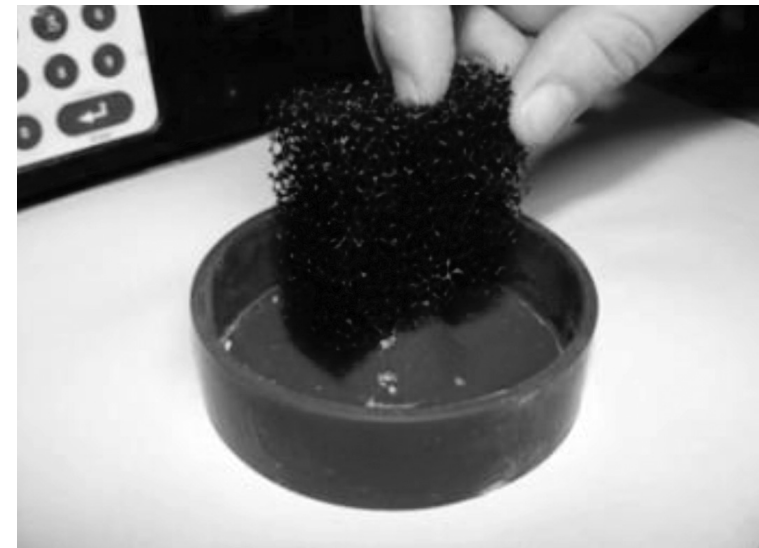

Figure 3: Polymer foam

Slika 3: Polimerna pena

the thermal conductivity of a material, its ability to dampen vibrations or to absorb energy. ${ }^{5}$

\section{EXPERIMENTAL WORK}

\subsection{Casting method of the metallic foam}

The most common foundry method for manufacturing metal foams with open pores is the method using a disposable evaporable polymeric pattern, creating polymeric foams (most commonly polyurethane foams - PU foams).

The process (Figure 2) consists of casting polymeric foam with a refractory material (Figures 3 and 4), followed by drying and annealing the mould when the foam pattern is evaporated. The molten metal is then poured in the resulting cavities. After removing the heat-resistant material the cast metal foam with open pores is obtained which is an exact copy of the foam pattern (Figures 5 and $\mathbf{6}$ ).

One of the key steps in this production process is the choice and processing of the material suitable for the manufacture of a mould - plaster in this case. In particular, the material for the mould manufacture must have

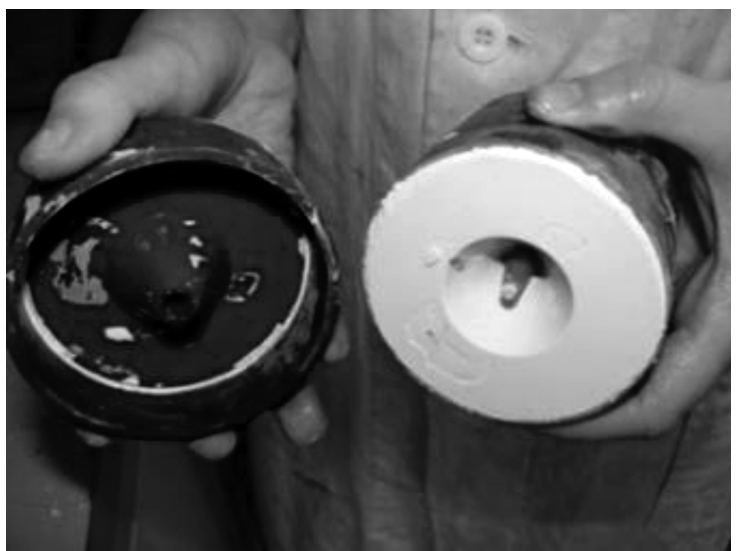

Figure 4: Plaster mould

Slika 4: Mavčna forma 


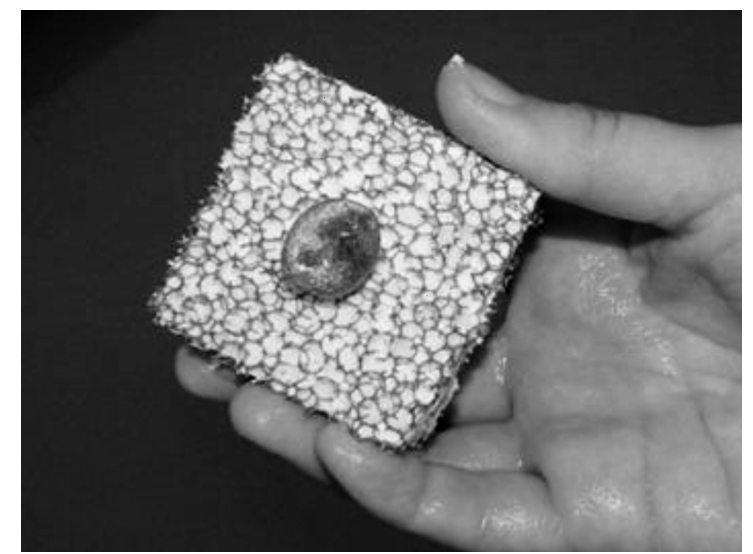

Figure 5: Metallic foam with remains of plaster mould Slika 5: Kovinska pena z ostanki mavčne forme

a sufficient heat resistance and the mixture must have a good fluidity to be able to fill all the small pores of the PU foam.

As the heat-resistant material for the manufacture of moulds, plaster Satin Cast 20 of the Kerr Lab firm was chosen for the casting of precious metals. This special plaster is a fine one and it can accurately copy the surface of a complex pattern. After casting the plaster shows an excellent collapsibility.

\subsection{Plaster-mould manufacture}

The plaster that serves as a filling material needs to be mixed in an exact proportion of water and plaster. One unit of water and two and a half units of plaster are used. It is appropriate to mix the plaster under a reduced pressure to avoid the formation of air bubbles which can negatively affect the plaster mould. Such a mould, after the thermal treatment, can crack or collapse under the influence of the expansion of the trapped air.

An Indu Mix device was used for mixing the plaster. It is fitted with a vibrating device that supports the elimination of air bubbles in the plaster after casting the plaster into the mould.

The plaster is mixed under a reduced pressure for five minutes followed by solidification in the presence of the vibrations for three minutes.

The making of a mould then consists of casting the pattern with the plaster and, at the same time, the plaster must fill all the pattern cavities. The pattern is stuck onto an accessory silicone hat that serves for creating a gate. A metal cover (cuvette) is put on the hat and the plaster is cast into the system prepared in such a way. The obtained moulds are left for two hours in the air and then they are dried at a temperature of $40{ }^{\circ} \mathrm{C}$ for $2 \mathrm{~h}$.

After drying the moulds, the next step is their annealing. During annealing free water and chemically bound water are removed and the PU foam is evaporated.

For the casting of various alloys ( $\mathrm{Cu}$ alloys, $\mathrm{Al}$ alloys) it is necessary to define different annealing cycles. When casting the $\mathrm{Cu}$ alloys with a higher melting

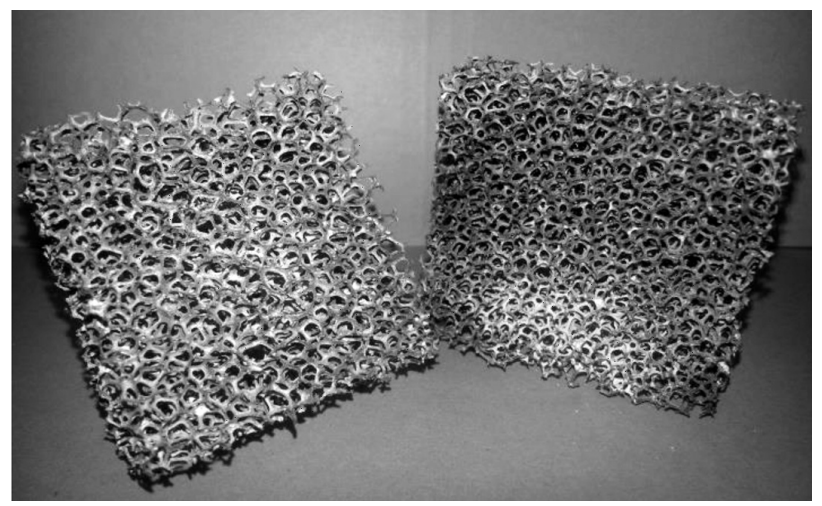

Figure 6: Metallic foam with an irregular cell structure with fully open pores

Slika 6: Kovinska pena $\mathrm{z}$ nepravilno razporeditvijo celic s popolnoma odprtimi porami

temperature (a higher casting temperature) it is necessary to anneal the plaster moulds at higher temperatures to eliminate the thermal shock during the casting, and to increase the melt fluidity in the complex mould cavity. The annealing cycles can be seen in Table $\mathbf{1}$.

Table 1: Annealing cycles for plaster moulds

Tabela 1: Cikli žarjenja mavčne forme

\begin{tabular}{|c|c|c|c|}
\hline & $\begin{array}{c}\text { temperature, } \\
\text { increase rate, } \\
\text { soaking time }\end{array}$ & $\begin{array}{c}\text { temperature, } \\
\text { increase rate, } \\
\text { soaking time }\end{array}$ & $\begin{array}{c}\text { temperature, } \\
\text { increase rate, } \\
\text { soaking time }\end{array}$ \\
\hline cycle 1 & $\begin{array}{c}120{ }^{\circ} \mathrm{C} \\
8{ }^{\circ} \mathrm{C} / \mathrm{min} ; 8 \mathrm{~h}\end{array}$ & $\begin{array}{c}320^{\circ} \mathrm{C} \\
10{ }^{\circ} \mathrm{C} / \mathrm{min} ; 8 \mathrm{~h}\end{array}$ & $\begin{array}{c}800^{\circ} \mathrm{C} \\
20 \mathrm{C} / \mathrm{min} ; 10 \mathrm{~h}\end{array}$ \\
\hline cycle 2 & $\begin{array}{c}120{ }^{\circ} \mathrm{C} \\
8{ }^{\circ} \mathrm{C} / \mathrm{min} ; 8 \mathrm{~h}\end{array}$ & $\begin{array}{c}550{ }^{\circ} \mathrm{C} \\
10^{\circ} \mathrm{C} / \mathrm{min} ; 8 \mathrm{~h}\end{array}$ & $20{ }^{\circ} \mathrm{C} / \mathrm{min} ; 10 \mathrm{~h}$ \\
\hline cycle 3 & $\begin{array}{c}120{ }^{\circ} \mathrm{C} \\
8{ }^{\circ} \mathrm{C} / \mathrm{min} ; 8 \mathrm{~h}\end{array}$ & $\begin{array}{c}550{ }^{\circ} \mathrm{C} \\
{ }^{\circ} \mathrm{C} / \mathrm{min} ; 8 \mathrm{~h}\end{array}$ & $20^{\circ} \mathrm{C} / \mathrm{min} ; 10 \mathrm{~h}$ \\
\hline
\end{tabular}

The most commonly used is the annealing cycle No. 1 suitable for the subsequent casting of $\mathrm{Al}$ alloys (a low melting temperature or a low casting temperature).

But for the casting of $\mathrm{Cu}$ and $\mathrm{Fe}$ alloys it is necessary to increase the annealing temperature, i.e., to heat the moulds to higher temperatures. Therefore, the annealing cycle No. 2 was recommended. However, this annealing cycle proved to be unsuitable - the moulds annealed at

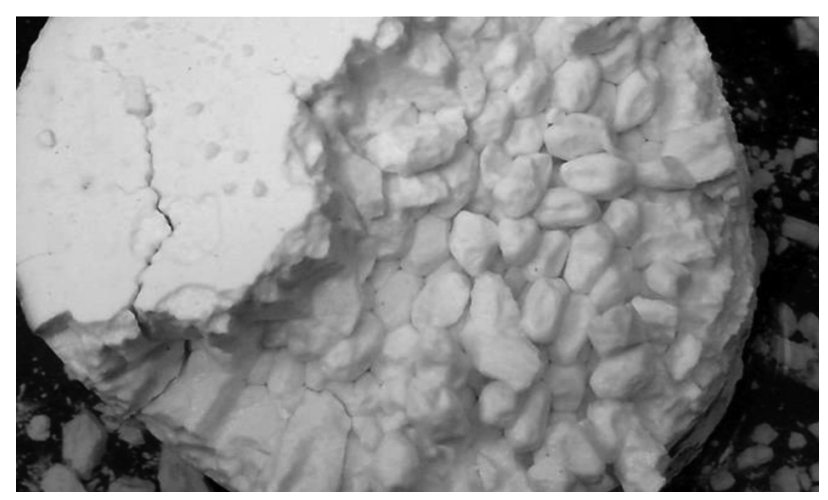

Figure 7: Plaster mould annealed at $1100^{\circ} \mathrm{C}$

Slika 7: Mavčna forma, žarjena na $1100^{\circ} \mathrm{C}$ 


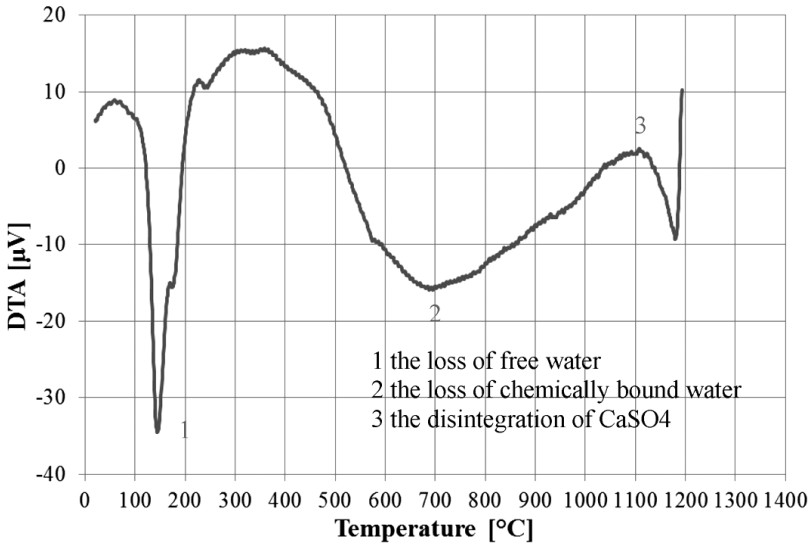

Figure 8: DTA of the Satin Cast plaster

Slika 8: DTA mavca vrste Satin Cast

such high temperatures showed an impaired collapsibility after the metal casting (Figure 7).

A plaster sample was subjected to a differential thermal analysis (DTA) which showed that, at the temperature of $1100{ }^{\circ} \mathrm{C}, \mathrm{CaSO}_{4}$ disintegrated into $\mathrm{CaO}$ and $\mathrm{SO}_{3}$ (a degradation of the mould).

After the evaluation of the plaster DTA the annealing cycle No. 3 was designed. The moulds annealed in such a way have a good collapsibility after the casting, but for casting the $\mathrm{Cu}$ and $\mathrm{Fe}$ alloys the mould temperature is too low. When casting these alloys, the metal fails to fill in the entire mould cavity due to a high-temperature jump. On the contrary, when casting the Al alloys the mould prepared in such a way is overheated.

\section{RESULTS AND DISCUSSION}

\subsection{Differential thermal analysis (DTA)}

When designing individual annealing cycles it was found that after annealing a plaster mould at the temperature of $1100{ }^{\circ} \mathrm{C}$ this mould lost its collapsibility. Therefore, the plaster sample was subjected to a differential thermal analysis (Figure 8). This is based on the measurement of the temperature difference between the test sample and the reference sample (the standard).

The basic requirements for the reference sample are as follows: the inertness and stability (no phase transformation can be present) in the measured temperature interval.

After the differential thermal analysis (DTA) three significant changes can be observed on the resulting curve (Figure 8). The first range $\left(150{ }^{\circ} \mathrm{C}\right)$ represents the loss of free water, while the second one represents the loss of chemically bound water $\left(700{ }^{\circ} \mathrm{C}\right)$. The third area $\left(1100{ }^{\circ} \mathrm{C}\right)$ shows the disintegration of $\mathrm{CaSO}_{4}$ into $\mathrm{CaO}$ and $\mathrm{SO}_{3}$ due to high temperatures. This process is irreversible and the moulds annealed in such a way are unusable due to the loss of good collapsibility after the casting. If the annealing temperature is reduced to the maximum of $1000{ }^{\circ} \mathrm{C}, \mathrm{CaSO}_{4}$ does not disintegrate and the plaster (together with the plaster mould) maintains its optimum properties.

\section{CONCLUSION}

With the technology using polymeric foam as a disposable combustible pattern, liquid metal is poured into a mould cavity that is an exact negative of the original foam pattern.

Proper choice and processing of a material suitable for manufacturing the mould are then essential for this production process. In particular, the material must show a sufficient heat-resistance and the mixture must have a good fluidity to fill in all the small pores of the polyurethane foam.

Thus, plaster (Satin Cast 20) is the ideal solution - it can accurately copy the complex shape of a foam pattern and, at the same time, resisting high temperatures. The key step of making the resulting plaster mould is then the annealing cycle. The annealing cycle must allow the moulds to be annealed at a sufficiently high temperature to avoid a heat shock or a misrun when the metal fails to fill in the entire mould cavity. At the same time, however, the annealing cycle should not exceed the temperature at which a degradation of the plaster mould occurs in the case of the Satin Cast 20 plaster it is $1100{ }^{\circ} \mathrm{C}$.

\section{Acknowledgements}

This work was carried out within research project TA02011333 supported by the Technology Agency of the Czech Republic and project of specific research VŠB-TU Ostrava - SP 2014/61.

\section{REFERENCES}

${ }^{1}$ P. Lichý, V. Bednářová, T. Elbel, Casting routes for porous metals production, Archives of Foundry Engineering, 12 (2012) 1, 71-74, doi:10.2478/v10266-012-0014-0

${ }^{2}$ J. Banhart, Manufacturing routes for metallic foams, Journal of Minerals, Metals and Materials, 52 (2000) 12, 22-27, doi:10.1007/ s11837-000-0062-8

${ }^{3}$ V. Bednářová, P. Lichý, T. Elbel et al., Cast cellular metals with regular and irregular structures, Mater. Tehnol., 48 (2014) 2, 175-179

${ }^{4}$ J. Banhart, Manufacture, characterisation and application of cellular metals and metal foams, Progress in Materials Science, 46 (2001) 6, 559-632, doi:10.1016/S0079-6425(00)000020-5

${ }^{5}$ D. Curran, Aluminium Foam Production Using Calcium Carbonate as a Foaming Agent [online], PhD. Thesis, University of Cambridge, Cambridge, 2003, 188 [cit. 2010-12-10]; http://www.msm.cam.ac.uk/ mmc/publications/thesis/200312_DCC_PhD_thesis.pdf 